\title{
Transgressive Segregants for Qualitative and Quantitative Traits in Chickpea
}

\author{
Priyanka Joshi ${ }^{1,2^{*}}$, Mohammad Yasin ${ }^{2}$ and Prity Sundaram ${ }^{1,3}$ \\ ${ }^{1}$ International Crops Research Institute for the Semi-Arid Tropics, Hyderabad, India \\ ${ }^{2}$ RVSKVV, RAK College of Agriculture, Sehore - 466001 (M.P.), India \\ ${ }^{3}$ Bihar Agricultural University, Sabour, Bhagalpur - 813210, Bihar, India \\ *Corresponding author
}

\begin{tabular}{|l|}
\hline K e y w o r d s \\
Chickpea, RILs, \\
Transgressive \\
segregants, \\
Reproductive phase \\
\hline Article Info \\
\hline $\begin{array}{l}\text { Accepted: } \\
\text { 04 October } 2018 \\
\text { Available Online: } \\
\text { 10 November } 2018\end{array}$ \\
\hline
\end{tabular}

A B S T R A C T

Rich genetic potential with wide spectrum of genetic variability is a key factor behind a successful breeding programme. New recombinants can be generated through crossing between highly diverse parents. Genetically diverse 281 RILs and their parents were grown in randomized block design in two replications under rainfed and irrigated conditions during rabi 2011-12 and 2012-13. Categorization of RILs was done by using standard statistical procedure based on qualitative and quantitative traits. RILs were evaluated for traits name. Transgressive variations and their new combinations with other traits had been identified for presence of stem pigmentation, pink flower colour, dark green leaves, erect growth habit, brown seed colour and rough seed surface in RILs those are similar to kabuli type and no-pigmentation in stem, white flower and light colour leaves recorded similar to desi type RILs. Pea-shaped (microsperma type) RILs identified with white flower, non-pigmented stem, large leaves, variation in seed colour and surface. New variations were observed in qualitative traits as well as new recombination of various traits in angular, owl's head and pea-shaped groups of RILs. The best RILs identified for different traits include RILs 31 and 33 (early flowering), RIL 77 (late flowering), RILs 33 and 12 (early maturity), RILs 120 and 109 (reproductive phase duration, biological yield, harvest index and plant canopy), and RILs 41 and 109 (seed yield) under both irrigated and rainfed conditions. The identified RILs with desirable trait combinations can be utilised in chickpea breeding programme for seeking improvement in yield and its component traits.

\section{Introduction}

On global basis, Chickpea [Cicer aeritinum L.] is the second most important pulse crop after dry beans and dry peas. Although predominantly consumed as a pulse, dry chickpea is also used in preparing a variety of snack foods, sweets and condiments (Saxena, 1987). Variability is the most distinctive feature of crop species and provides the foundation for plant improvement. So the amount of variation has to be considered and assessed. The development of an effective plant breeding programme depends upon the existence of genetic variability present in gene pool. The efficiency of selection largely depends upon the magnitude of genetic variability present in the genetic stock. The 
extent of variability for various qualitative and quantitative traits including seed yield available to breeders determine the success that can be achieved in genetic improvement and development of good plant type. RIL's population comprising 281 lines developed by crossing two contrast genotypes viz., ICC 283 (desi; microsperma type) and ICC 8261 (kabuli; macrosperma type). Parents and RILs were evaluated for different agronomical \& yield traits.

\section{Materials and Methods}

The present investigation was carried out at research field of R.A.K. College of Agriculture, Sehore (M.P.) during rabi season of 2011-12 and 2012-13. The experimental material consisted of 281RILs'population derived from a cross between ICC 283 (Desi; microsperma type) and ICC 8261 (Kabuli; macrosperma type), provided by International Crops Research Institute for the Semi-Arid Tropics, Patancheru (Telangana). Based on seed shape, size and colour, cultivated chickpeas are of two types (Cubero, 1975).

Microsperma (desi type). The seeds of this type chickpea are small and angular in shape. Seeds colour varies from cream, black, brown, yellow to green. The plant was short with small leaflets and purplish flowers, and contains anthocyanin.

Macrosperma (kabuli type). The seeds of this type chickpea are large (100-seed mass >25 g), owl's head shape, and cream-coloured. The plant was medium to tall in height, with large leaflet size and white flowers, and contains no anthocyanin.

A set of 281RIL's population and their parents were grown in randomized block design with two replications under two moisture regimes viz., irrigated and rainfed. Each entry was sown in $4 \mathrm{~m}$ long single row with $30 \mathrm{~cm}$ row- to-row and $10 \mathrm{~cm}$ plant-to-plant spacing. The fertilizer dose 20:50:0:20 NPKS $\mathrm{kg} / \mathrm{ha}$ was applied as basal dose. Recommended package practices were adopted for optimum crop growth and plant protection under rainfed and irrigated conditions.

The traits assessed were seed shape, seed colour, leaf colour, leaf size, flower colour, plant growth habit, days to $50 \%$ flowering, days to maturity, plant height, biological yield/ plant, seed yield/plant, harvest index and 100seed weight. Data were recorded using guidelines of International chickpea descriptor (1993) on five plants from each lines.

\section{Results and Discussion}

The present investigation was targeted to assess new recombination and transgressive variations generated in RIL's population for six qualitative and nine quantitative traits.

\section{Qualitative traits}

A set of 281 RILs' population were grouped on the basis of seed shape into three categories viz.; angular, owl's head and pea-shaped.

Seed shape: ICC 283 had angular shape and ICC 8261 owl's head shape. In RIL's population, three types of seed shape viz., angular, owl's head and pea shaped were recorded. The population were broadly divided into two group i.e. parental type and recombinant type. RILs (36.29\%) were identified as ICC 283 and $26.33 \%$ as ICC 8261 , whereas $37.36 \%$ as new recombinant type i.e. pea-shaped (Fig. 1). Occurrence of new transgressive variations in seed shape provided a new dimension for chickpea research. Pea-shaped chickpea have major demand for roasting and parching purposes. A combination of pea-shaped seed with white and pink seed coat will be helpful in cross breeding programme to develop varieties as 
per the need and demand of market. Among 211 accessions of minicore subset of chickpea, three types of seed shapes reported by Upadhyaya et al., (2001) and grouped as angular (159, Desi types), owl's head (44, Kabuli types) and pea shaped (8, intermediate types). According to Knight (1979), the inheritance study of seed shape in chickpea indicated that pea- shape of seed is dominant over both desi and kabuli, and desi is dominant over kabuli shape. In this investigation, frequency of parent I type is angular shape seed phenotype is higher as compared to parent II type i.e. owl's head shape.

Seed colour: ICC 283 was brown seeded and ICC 8261 was creamy-white which resulted RILs with a range of variation in seed colour. Among the RILs, $52.66 \%$ showed similarity to ICC 283 and $19.57 \%$ with ICC 8261, whereas $27.75 \%$ lines had different colour of seed as compare to both the parents (Table 1 and Fig. 2). Significantly different picture for variation in seed colour was also recorded in various groups of RILs (Plate 2). In angular shape group of RILs $14.70 \%$ having creamy-white and owl's head shape group of RILs, $18.91 \%$ with brown seed colour, while surprisingly $27.75 \%$ RILs seed colour was varied from both the parents.

It was observed as unexpected recombinations, but most desired recombination in desi group due to creamywhite seed colour and in kabuli group with brown seed colour. These RILs will be helpful in designing new seed colour combination to meet out the demand of national and international market. Coloured seed coat was dominant over salman white found by Tefera (1998) and reported this coating probably due to controlled by three pairs of genes. Variations generated in RILs can be used for the development of new lines especially in kabuli and intermediate categories. In relation to the appearance of new seed coat colour recombination could be due to gene interaction.

Leaf colour: ICC 283 and ICC 8261 had dark and light green leaf, respectively. Among the RILs, $58.36 \%$ had dark green leaf and $41.63 \%$ had light green leaf (Fig. 3). No new recombinants were identified for leaf colour. Twenty three RILs showed dark green leaf in kabuli group indicating leaf colour was shifted from desi to kabuli type (Table 1). Dark green leaf in kabuli group can be utilized for the better photosynthesis rate in cross breeding programme. In chickpea, purple and light green colours of leaf were noted by Rao et al., (1980) due to mono-factorial recessive inheritance.

Leaflet size: Among the RILs, small (32.38\%), medium (57.65\%) and large $(9.96 \%)$ leaflet size was observed, while both the parents had no small leaflets. Presence of small leaflet in RILs will provide a drought resistant donor for cross breeding programme in the development of drought tolerant varieties in chickpea. In general, kabuli chickpea possess large leaflet, whereas in the present investigation small leaflet bearing RILs were also found. These RILs may help in developing moisture tolerant kabuli varieties. Variation in leaflet size was also reported by (Singh and Tuwafe, 1981; Raje and Khare, 1996 and Robertson et al., 1997) in germplasm of chickpea (Table 1 and Fig. 4).

Flower colour: In desi chickpea pink flower is prominent and it was recorded in $55.87 \%$ of RILs but $1.77 \%$ RILs had blue flower (Fig. 5). It was an encouraging observation in shifting of flower colour that in angular shape RILs $(33.33 \%)$ showed white flower which was not present in the microsperma parent, in owl's head shape RILs $27.02 \%$ had pink flowers and in pea shaped RILs (29.52\%) showed white flowers. This was unexpected new 
recombination observed for flower colour traits (Table 1). Shifting of flower colour from angular type to pea shaped and owl's head shape RILs and owl's shape to pea and angular shape group was because of independent assortment of genes and transgressive recombination in RILs. Tefera (1998) reported monogenic inheritance pattern of pink vs. white flower colour in RILs (ICCV $2 \times$ JG 62) of chickpea. Shifting of genes responsible for flower colour from desi to kabuli and vice-versa indicating oligogenic genetic control in flower colour, which has also been observed in the present investigation.

Plant growth habit: ICC 283had semispreading and ICC 8261 semi-erect growth habit. Four types of plant growth habit were recorded in RILs' population. Spreading and prostrate growth habit was recorded in 45.19\% and $4.27 \%$ RILs, respectively as new recombinant type. RILs, $36.65 \%$ was identified as semi-spreading type. While, $13.87 \%$ RILs was semi-erect type (Table 1 and Fig. 6).

Variations was also observed in angular categories where $20.58 \%$ RILs was semierect, $45.05 \%$ semi-spreading, $3.92 \%$ prostrate and $30.39 \%$ spreading type. Similarly in owl's head shaped prostrate $(4.05 \%)$, semi-erect $(9.45 \%)$, spreading $(59.45 \%)$ and $27.02 \%$ semi-spreading plant growth habit was recorded. In pea shaped RILs group 10.47\% semi erect, $4.76 \%$ prostrate, $35.23 \%$ semi spreading and $49.52 \%$ spreading type was recorded, all above observations showed unexpected recombination for plant growth habit in RILs population which was not present in their parents. Changes in plant growth habit can bring a major revolution in the development of new plant type especially in kabuli group which is a long awaited desire of a plant breeding programme. In cognizance of the above, other studies may be mentioned here viz., Rao et al., (1980) reported monofactorial recessive gene inherited prostrate growth habit in chickpea.

\section{Quantitative traits}

Nine quantitative traits were recorded in RIL population along with the parents and analyzed for comparative assessment of variation generated due to recombination under rainfed (stress) and irrigated (favourable) conditions.

Days to $50 \%$ flowering: High range for days to $50 \%$ flowering was recorded in RIL's population. Twenty days earlier in RIL as compared to ICC 283 (73 days) type and 22 days earliness as compared to macrosperma (63 days). ICC 283 flowered at 73 days and ICC 8261 flowered at 63 days under irrigated condition. In rainfed condition both the parent flowered one day earlier as compare to irrigated. In RILs population changes observed in both the extreme site. For RIL 0031 and RIL 0033 days to $50 \%$ flowering were 41 and 43 days under irrigated and rainfed conditions respectively. The RIL 0031 exhibited 22 days earlier flowering as compared to their early parent (Table 2). Similarly in RIL no. 77, 93 and 90 days for $50 \%$ flowering was recorded which is about 20 days and 18 days more period as compared to their higher parents. These RILs can be used as parents for recombination breeding programme for development of early flowering variety. Sidramappa et al., (2008) also reported similar finding as observed in the present findings.

Days to maturity: Fluctuation was observed in maturity period of RILs' population in both the conditions as compared to parents. RIL 0002 matured in 107 days, whereas RIL 0077 matured at 131 days. Change in maturity period is a good sign for better selection and their utilization (Table 2). 
Table.1 Relative frequency of different qualitative traits in total RILs and RILs classes (viz., angular, owl's head and pea shape seed) of chickpea

\begin{tabular}{|c|c|c|c|c|c|c|c|c|c|}
\hline \multirow[t]{4}{*}{ Traits } & \multirow[t]{4}{*}{ Type of traits } & \multicolumn{2}{|c|}{ RILs } & \multicolumn{6}{|c|}{ Total RILs divided into three groups on the basis of seed shape } \\
\hline & & \multirow[t]{2}{*}{ Total } & \multirow[t]{2}{*}{281} & \multicolumn{2}{|c|}{ Angular } & \multicolumn{2}{|c|}{ Owl's head } & \multicolumn{2}{|c|}{ Pea } \\
\hline & & & & \multicolumn{2}{|c|}{102 RILs } & \multicolumn{2}{|c|}{74 RILs } & \multicolumn{2}{|c|}{105 RILs } \\
\hline & & Frequency & $\%$ & Frequency & $\%$ & Frequency & $\%$ & Frequency & $\%$ \\
\hline \multirow{2}{*}{$\begin{array}{l}\text { Leaf } \\
\text { colour }\end{array}$} & Dark green & 165 & 58.36 & 68 & 66.66 & 23 & 31.08 & 74 & 70.47 \\
\hline & Light green & 116 & 41.63 & 34 & 33.33 & 51 & 68.91 & 31 & 29.52 \\
\hline \multirow[t]{3}{*}{ Leaf size } & Small & 91 & 32.38 & 32 & 31.37 & 14 & 18.91 & 42 & 40 \\
\hline & Medium & 162 & 57.65 & 63 & 61.76 & 47 & 63.51 & 55 & 52.38 \\
\hline & Large & 28 & 9.96 & 7 & 6.86 & 13 & 17.56 & 8 & 7.61 \\
\hline \multirow{3}{*}{$\begin{array}{l}\text { Flower } \\
\text { colour }\end{array}$} & Pink & 157 & 55.87 & 65 & 63.72 & 20 & 27.02 & 72 & 68.57 \\
\hline & White & 119 & 42.34 & 34 & 33.33 & 54 & 72.97 & 31 & 29.52 \\
\hline & Blue & 5 & 1.77 & 3 & 2.94 & 00 & 00 & 2 & 1.90 \\
\hline \multirow{4}{*}{$\begin{array}{l}\text { Plant } \\
\text { growth } \\
\text { habit }\end{array}$} & Semi-erect & 39 & 13.87 & 21 & 20.58 & 7 & 9.45 & 11 & 10.47 \\
\hline & Semi-spreading & 103 & 36.65 & 46 & 45.09 & 20 & 27.02 & 37 & 35.23 \\
\hline & Spreading & 127 & 45.19 & 31 & 30.39 & 44 & 59.45 & 52 & 49.52 \\
\hline & Prostrate & 12 & 4.27 & 4 & 3.92 & 3 & 4.05 & 5 & 4.76 \\
\hline \multirow{3}{*}{$\begin{array}{l}\text { Seed } \\
\text { colour }\end{array}$} & Brown & 148 & 52.66 & 83 & 81.37 & 14 & 18.91 & 50 & 47.61 \\
\hline & Creamy-white & 55 & 19.57 & 15 & 14.70 & 41 & 55.40 & 00 & 00 \\
\hline & $\begin{array}{l}\text { Varied from both } \\
\text { the parents }\end{array}$ & 78 & 27.75 & 4 & 3.92 & 19 & 25.67 & 55 & 52.38 \\
\hline
\end{tabular}

Table.2 Variability in quantitative traits in parents and RILs population under rainfed and irrigated conditions

\begin{tabular}{|c|c|c|c|c|c|c|c|c|}
\hline \multirow{3}{*}{$\begin{array}{l}\text { S. } \\
\text { No. }\end{array}$} & \multirow{3}{*}{$\begin{array}{l}\text { Quantitative } \\
\text { traits }\end{array}$} & \multirow{3}{*}{$\begin{array}{l}\text { Condition } \\
\text { s for trial }\end{array}$} & \multicolumn{2}{|c|}{ Values in Parent } & \multicolumn{4}{|c|}{ Values in RILs } \\
\hline & & & \multirow{2}{*}{$\begin{array}{l}\text { ICC } 283 \\
\text { (Parent I) } \\
\text { Microsperma }\end{array}$} & \multirow{2}{*}{$\begin{array}{l}\text { ICC 8261 } \\
\text { (Parent II) } \\
\text { Macrosperma }\end{array}$} & \multicolumn{2}{|c|}{$\begin{array}{l}\text { Range in RIL } \\
\text { population }\end{array}$} & \multicolumn{2}{|c|}{$\begin{array}{l}\text { Values lesser or greater } \\
\text { than parents }\end{array}$} \\
\hline & & & & & Min. & Max. & $\begin{array}{l}\text { Values } \\
\text { lower than } \\
\text { minimum } \\
\text { parental } \\
\text { value }\end{array}$ & $\begin{array}{l}\text { Values } \\
\text { higher than } \\
\text { above } \\
\text { parental } \\
\text { value }\end{array}$ \\
\hline \multirow[t]{2}{*}{1} & \multirow{2}{*}{$\begin{array}{l}\text { Days to } 50 \% \\
\text { flowering }\end{array}$} & Irrigated & 73 & 63 & 41 & 93 & 22 & 20 \\
\hline & & Rainfed & 72 & 62 & 43 & 90 & 19 & 18 \\
\hline \multirow[t]{2}{*}{2} & \multirow{2}{*}{$\begin{array}{l}\text { Days to } \\
\text { maturity }\end{array}$} & Irrigated & 119 & 128 & 107 & 131 & 12 & 3 \\
\hline & & Rainfed & 118 & 121 & 106 & 129 & 12 & 8 \\
\hline \multirow[t]{2}{*}{3} & \multirow{2}{*}{$\begin{array}{l}\text { Plant canopy } \\
(\mathrm{cm})\end{array}$} & Irrigated & 39.6 & 44.3 & 12.7 & 56.0 & 26.9 & 11.7 \\
\hline & & Rainfed & 38 & 41 & 13.8 & 54 & 24.2 & 13 \\
\hline \multirow[t]{2}{*}{4} & \multirow[t]{2}{*}{ Pods / plant } & Irrigated & 42 & 46 & 12 & 111 & 30 & 65 \\
\hline & & Rainfed & 37 & 41 & 6 & 95 & 31 & 54 \\
\hline \multirow[t]{2}{*}{5} & \multirow[t]{2}{*}{ Seeds / plant } & Irrigated & 52 & 31 & 13 & 112 & 18 & 60 \\
\hline & & Rainfed & 21 & 21 & 7 & 103 & 14 & 82 \\
\hline \multirow[t]{2}{*}{6} & \multirow{2}{*}{$\begin{array}{l}\text { Biological } \\
\text { yield/ plant }(\mathrm{g})\end{array}$} & Irrigated & 24.5 & 24.6 & 7.1 & 43.6 & 17.4 & 19 \\
\hline & & Rainfed & 18.5 & 19.8 & 6.3 & 38.1 & 12.2 & 28.22 \\
\hline \multirow[t]{2}{*}{7} & \multirow{2}{*}{$\begin{array}{l}\text { Seed yield/ } \\
\text { plant }(\mathrm{g})\end{array}$} & Irrigated & 8.80 & 9.80 & 1.73 & 38.02 & 7.07 & 28.22 \\
\hline & & Rainfed & 6.40 & 9.40 & 1.2 & 12.78 & 5.2 & 3.38 \\
\hline \multirow[t]{2}{*}{8} & \multirow{2}{*}{$\begin{array}{l}\text { Harvest index } \\
(\%)\end{array}$} & Irrigated & 32.92 & 36.13 & 7.43 & 49.34 & 25.49 & 13.21 \\
\hline & & Rainfed & 34.47 & 31.54 & 2.09 & 48.80 & 29.45 & 14.33 \\
\hline \multirow[t]{2}{*}{9} & \multirow{2}{*}{$\begin{array}{l}\text { Hundred seed } \\
\text { weight }(\mathrm{g})\end{array}$} & Irrigated & 14.2 & 30.6 & 6.2 & 34.5 & 8.0 & 3.9 \\
\hline & & Rainfed & 14.4 & 30.2 & 6.0 & 34.9 & 8.4 & 4.7 \\
\hline
\end{tabular}


Table.3 Range of flowering period in irrigated \& rainfed condition in RILs and their parentsof chickpea

\begin{tabular}{|c|c|c|c|c|}
\hline & $\begin{array}{l}\text { Conditions } \\
\text { for trial }\end{array}$ & $\begin{array}{l}\text { Minimum days to } \\
50 \% \text { flowering }\end{array}$ & $\begin{array}{l}\text { Maximum days to } \\
50 \% \text { flowering }\end{array}$ & $\begin{array}{l}\text { Range value (in } \\
\text { days) }\end{array}$ \\
\hline \multirow{2}{*}{$\begin{array}{l}\text { In both the } \\
\text { parents }\end{array}$} & Irrigated & 63 & 73 & 10 \\
\hline & Rainfed & 62 & 72 & 10 \\
\hline \multirow{2}{*}{$\begin{array}{l}\text { In RIL } \\
\text { population }\end{array}$} & Irrigated & 41 & 93 & 52 \\
\hline & Rainfed & 43 & 89 & 46 \\
\hline
\end{tabular}

Table.4 Variation in duration of reproductive phase in RILs and their parents of chickpea

\begin{tabular}{|l|l|c|c|c|}
\hline S. No. & RIL identified & $\begin{array}{c}\text { Days to } \mathbf{5 0} \% \\
\text { flowering }\end{array}$ & $\begin{array}{c}\text { Days to } \\
\text { maturity }\end{array}$ & $\begin{array}{c}\text { Duration of } \\
\text { reproductive phase }\end{array}$ \\
\hline $\mathbf{1}$ & RIL 0031 & 41 & 126 & $>85$ days \\
\hline $\mathbf{2}$ & RIL 0033 & 44 & 120 & $75-84$ days \\
\hline $\mathbf{3}$ & RIL 0001 & 47 & 112 & $65-74$ days \\
\hline $\mathbf{4}$ & RIL 0108 & 56 & 119 & $55-64$ days \\
\hline $\mathbf{5}$ & RIL 0002 & 55 & 107 & $45-54$ days \\
\hline $\mathbf{6}$ & Parent I & 73 & 119 & 46 days \\
\hline 7 & Parent II & 63 & 121 & 58 days \\
\hline
\end{tabular}

Table.5 Superior RILs identified for yield and yield attributes in both irrigated \& rainfed conditions

\begin{tabular}{|c|c|c|c|}
\hline \multirow{2}{*}{$\begin{array}{l}\text { Yield contributing } \\
\text { traits }\end{array}$} & \multirow[t]{2}{*}{ New range in traits } & \multicolumn{2}{|c|}{ Superior RILs Identified } \\
\hline & & $\begin{array}{l}\text { Irrigated } \\
\text { condition }\end{array}$ & Rainfed condition \\
\hline \multirow{2}{*}{$\begin{array}{l}\text { Days to } 50 \% \\
\text { flowering }\end{array}$} & Early flowering & RIL 31 (41 days) & RIL 33 (43 days) \\
\hline & Late flowering & RIL 77 (93 days) & RIL 77 (90 days) \\
\hline \multirow[t]{2}{*}{ Days to maturity } & Early maturity & RIL 33 (107 days) & RIL 12 (131 days) \\
\hline & Late maturity & RIL 12 (131 days) & RIL 75 (129 days) \\
\hline Reproductive phase & Long & RIL 31 (>85 days) & RIL 33 (76 days) \\
\hline \multirow[t]{2}{*}{ Plant height (cm) } & Taller & RIL $245(56.0 \mathrm{~cm})$ & RIL $109(54.0 \mathrm{~cm})$ \\
\hline & Smaller & RIL $120(12.7 \mathrm{~cm})$ & RIL $123(13.8 \mathrm{~cm})$ \\
\hline Biological yield (g) & $\begin{array}{l}\text { Higher than better } \\
\text { parent }\end{array}$ & RIL 245 (43.6g) & RIL 123 (38.1g) \\
\hline Seed yield (g) & $\begin{array}{l}\text { Higher than better } \\
\text { parent }\end{array}$ & RIL $52(38.02 \mathrm{~g})$ & RIL 123 (12.78g) \\
\hline Harvest index (\%) & $\operatorname{High}(\geq 48 \%)$ & RIL 245 (49.34\%) & RIL $123(48.8 \%)$ \\
\hline $\begin{array}{l}\text { Hundred seed weight } \\
\text { (g) }\end{array}$ & $\operatorname{High}(\geq 34 \mathrm{~g})$ & RIL 63 (34.9g) & RIL 63 (34.5g) \\
\hline
\end{tabular}


Fig.1

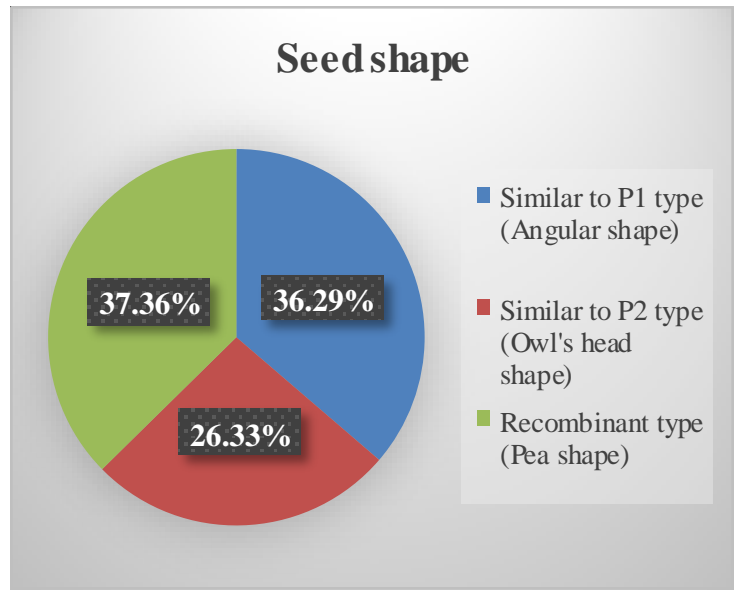

Fig.3

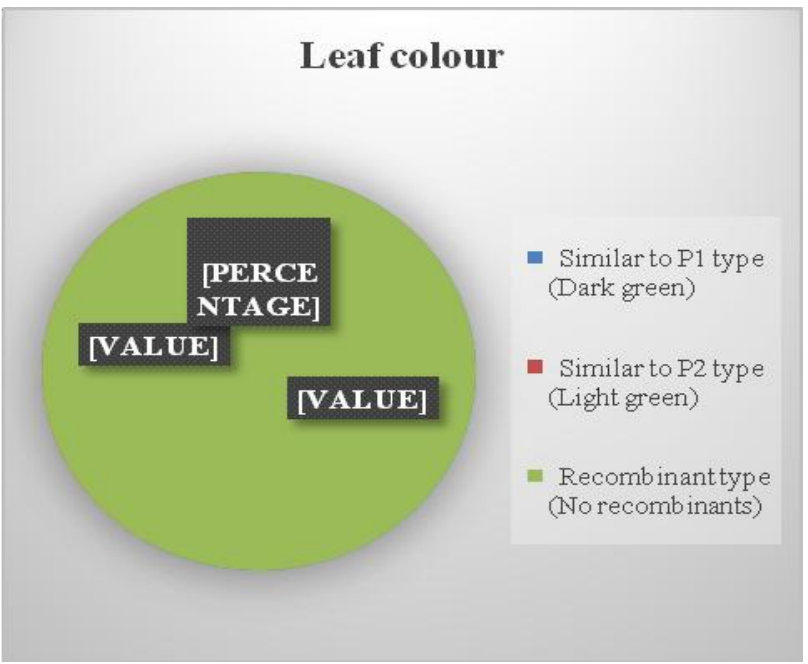

Fig.5

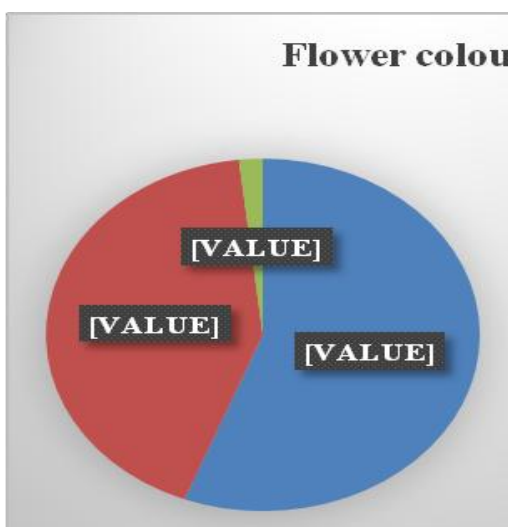

- Similar to P1 type (Pink)

- Similar to P2 type (White)

- Recombinant type (Blue)

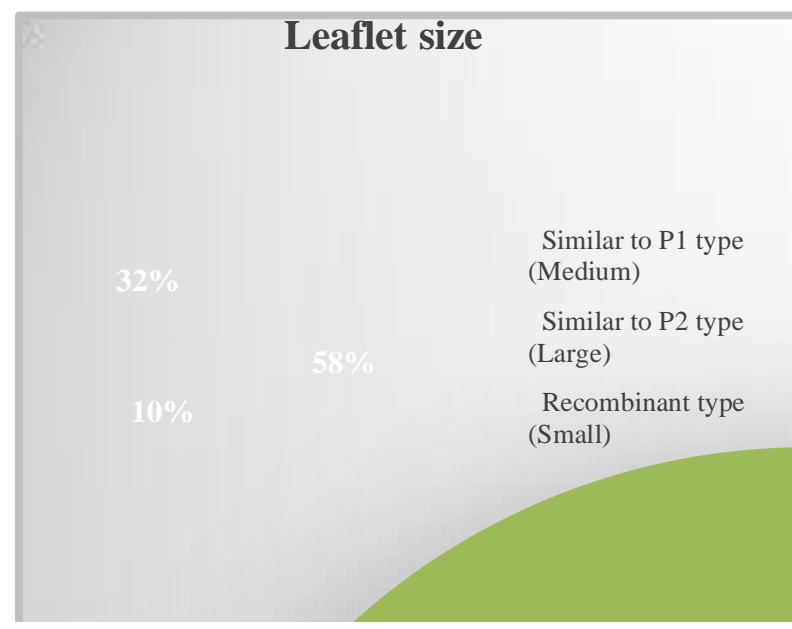

Fig.6
Fig.2

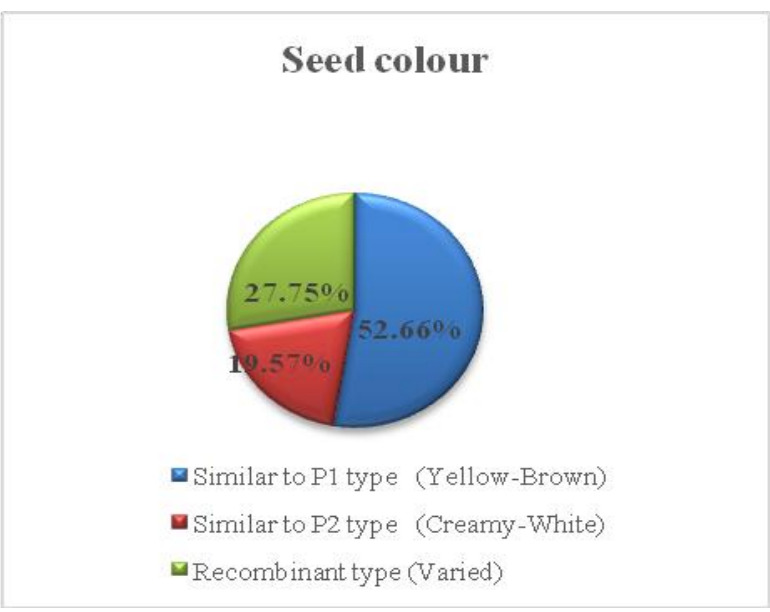

Fig.4
Large

Recombinant type

Similar to P1 typ (Semi-spreading)

- Similar to P2 type (Semi-erect)

= Recomb inant type (Spreading)

- Recombinant type (Prostrate) 

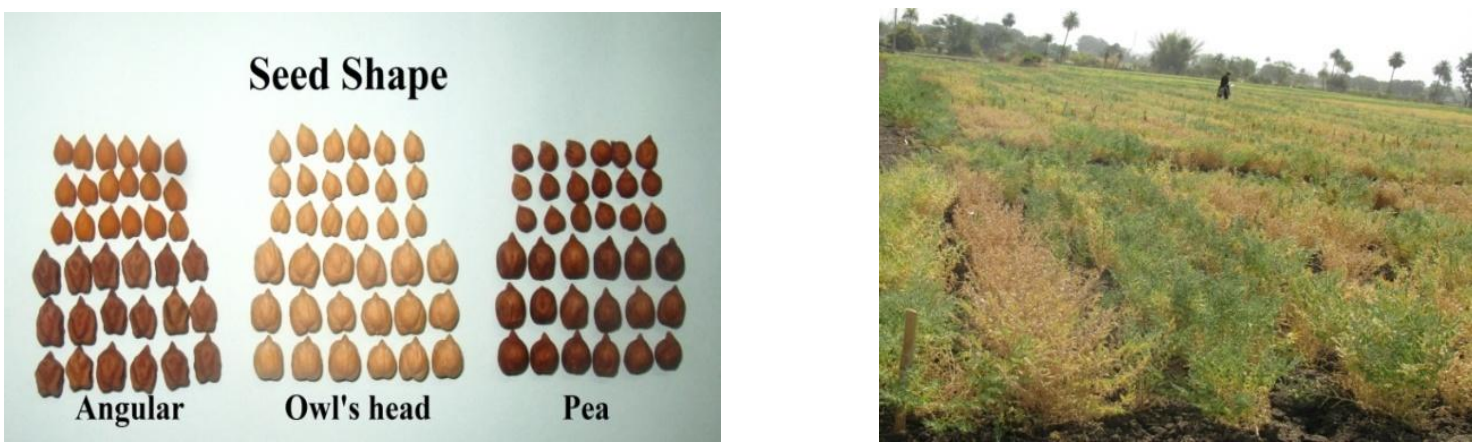

Plate.2 Showing different seed shapes of RILs (a) with various seed colours (b)

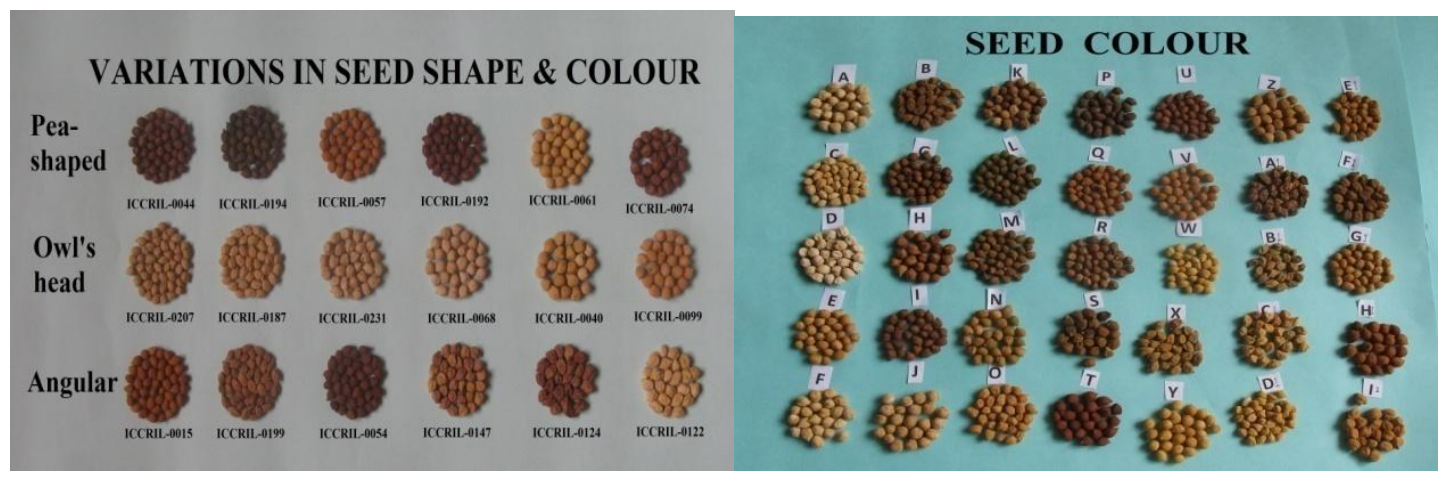

(a)

(b)

Plant canopy: Appearance of new plant growth habit in RILs' population due to recombination has resulted variation in plant canopy in both the extremes. Dwarf as well as tall plant height was identified in RILs' population. In RILs 0042 and 0030 dwarf plant canopy were recorded and taller canopy was observed in RIL 0123 (Table 2).

Reduction and increment in plant height was observed due to prostrate and erect plant growth habit respectively. Tall plant would be considered as favourable trait for mechanical harvesting.

Pods per plant: Variation in number of pods per plant was observed due to change in plant growth habit as well as their fertility status. Highest and lowest pod setting was recorded in RIL 0210 and 0023, respectively (Table 2). Variation in the range of pods per plant in
RIL population also reported by Sidramappa et al., (2008).

Seeds per plant: Minimum seed per plant was observed in RIL 0023 in both the conditions, whereas maximum seeds per plant were recorded for RIL 0210. Seed setting pattern exhibited similar situation and pattern as observed in pods per plant (Table 2).

Biological yield per plant: One irrigation promoted better condition for vegetative growth hence better biological yield was recorded in irrigated conditions in parental as well as in RILs population.

Lowest biological yield per plant was recorded in RIL 0231 and high in RIL 0091 under irrigated condition. Similarly, RIL 0095 had the lowest biological yield and the highest was for RIL 0128 under rainfed conditions. 
Plant growth habit also played a significant role in biological yield production. Sterile plants produced more biological yield as compared to fertile lines.

Seed yield per plant: In RIL population and parental population seed yield per plant was better under irrigated condition as compared to rainfed condition. In RIL 0071 under irrigated condition and in RIL 0224 under rainfed condition showed poorest seed yield. But RIL 0255 under irrigated condition and RIL0086 under rainfed condition showed better seed yield than their parents. Good seed yield in RIL was due its good plant type and better fertility status.

Harvest index: High harvest index is considered as a key factor of good economic yield and better plant type with optimum conversion of source to sink. In RIL population under rainfed and irrigated condition very low and nearer to good $(50 \%)$ harvest index was recorded. The lowest harvest index $(9.44 \%)$ was recorded in RIL 0224 whereas, the highest harvest index in RIL 0245 (49.34\%).

Hundred seed weight: ICC 283 was medium seeded $(14.2 \mathrm{~g} / 100$ seed) and ICC 8261 $(30.2 \mathrm{~g} / 100$ seed) bold seeded. In RILs the lowest hundred seed weight as recorded for RIL 0021 and the highest seed weight was for RIL 0062 (Table 2).

Variation in seed weight especially in desi group will be helpful in selection of bold seeded genotypes.

Duration of reproductive phase: Early flowering and delayed maturity provides long duration for reproductive phase. Long duration reproductive phase is helpful in the formation of more pods and more seed that resulted higher seed yield. Long duration of reproductive phase (85 days) was observed in RIL 0031 followed by RILs 0033 and 0001 and short duration of reproductive phase was for RIL 0002 (45 days) (Table 3). The variation in $50 \%$ flowering was high in irrigated condition as compared to rainfed condition (Table 4). This variation was identified due to plant growth habit and fertility status of RILs.

In this study, useful transgressive segregants were identified. RILs with pea-shaped seeds were identified as new recombinant. Highest degree of variation in seed colour was identified in RILs' population, these seed colours variation was much different from both the parents. Shifting and reallocation of qualitative traits from microsperma type to macrosperma type and vice versa was reported. In angular shaped RILs, appearance of white flower and light green colour leaves was identified due to recombination. Similarly in Kabuli i.e. owl's head seed shape, pink flower, presence of stem anthocyanin, dark green leaf colour and variation in plant growth habit was a remarkable reshuffling and recombination from desi group.

In RILs' population wider range in quantitative traits was also identified in comparison to their parental extreme values, change in 50\% flowering and maturity period has resulted in prolongation of duration of reproductive phase and vice versa.

Duration of reproductive phase ranged from 46 to 85 days for RILs. Whereas it was 46 days for $\mathrm{P}_{1}$ and 58 days to $\mathrm{P}_{2}$. Wider range of variation was also recorded for plant canopy, pods per plant, seeds per plant, biological yield, seed yield and harvest index in RILs in both condition. Remarkable new recombinants generated in RILs' population and these lines could be utilized in the development of new plant type in kabuli and desi types of chickpea.

\section{References}

Cubero, J.I., 1975. The research on chickpea (Cicer arietinum) in Spain. Pages 117122 in Proceedings of the International Workshop on Grain Legumes, 13-16 Jan 1975, ICRISAT, Hyderabad, India: International Crops Research Institute for the Semi-Arid Tropics. 
IBPGER, ICRISAT, ICARDA, 1993. Descriptors for chickpea (Cicer arietinum L.). International Board for Genetic Resources, Rome, Italy; International Crops Research Institute for the SemiArid Tropics, Patancheru, India and International Center for Agriculture Research in the Dry Areas, Aleppo, Syria.

Khan, Rozina, Farhatullah and Khan, Hamayoon, 2011. Dissection of genetic variability and heritability estimates of chickpea germplasm for various morphological markers and quantitative traits. Sarhad Journal of Agriculture. 27(1): 67-72.

Knights, E.J., 1979. Kabuli-Desi introgression: The experience in Australia. In Proceedings of the international workshop on chickpea improvement, Hyderabad, India. Pp. 70-74.

Raje, R.S., and Khare, D., 1996. Effect of seed size on seed yield and seedling vigour and quality attributes of chickpea. Indian Journal of Pulses Research. 9(1): 66-67.

Rao, N.K., Pundir, R.P.S., and Van Der Maesen, L.J.G., 1980. Inheritance of some qualitative characters in chickpea (Cicer arietinum L.). Indian Academy of Science (Plant Science). 89(6): 497-503.

Robertson, L.D., Ocampo, B., and Singh, K.B. 1997. Morphological variation in wild annual Cicer species in comparison to the cultigens. Euphytica, 95: 309-319.

Sabaghpour, Sayyed Hossain, Kumar Jagdish and Rao, T. Nageshwar, 2003. Genetic study of stem colour in chickpea (Cicer arietinum L.). In proceedings of
International conference on chickpea research for the millennium centre Raipur, India. pp 90-92.

Saxena, M.C., 1987. Problems and potential of chickpea production in the nineties. Proc. $2^{\text {nd }}$ Int. Workshop Chickpea Improvement. pp. 13-25.

Sidramappa, S.A. Patil, P.M. Salimath and S.T. Kajjidoni, 2008. Genetic Variation for Productivity and its Related Traits in a Recombinant Inbred Lines Population of Chickpea, Karnataka Journal of Agricultural Science. 21(4): 488-490.

Singh, K.B., and Tuwafe, S.1981. The collection, evaluation and the maintenance of kabuli chickpea germplasm of ICARDA. International chickpea newsletter. 4: 2-4.

Tefera, Fekadu, 1998. Association of morphological characters and fusarium wilt resistance with see yield in a Kabuli $\mathrm{x}$ Desi chickpea (Cicer arietinum L.) cross. M.Sc. Thesis, Acharya N.G. Ranga Agri. Uni., Hyderabad.

Upadhyaya, H.D., Bramel, P.J., and Singh, S., 2001. Development of chickpea core subset using geographic distribution and quantitative traits. Crop Science. 41: 206210.

Upadhyaya, H.D., Dwivedi, S.L., Gowda, C.L.L. and Singh, S.2007. Identification of diverse germplasm lines for agronomic traits in a chickpea (Cicer arietinum L.) core collection for use in crop improvement. Field Crops Research. 100, 320-326.

\section{How to cite this article:}

Priyanka Joshi, Mohammad Yasin and Prity Sundaram. 2018. Transgressive Segregants for Qualitative and Quantitative Traits in Chickpea. Int.J.Curr.Microbiol.App.Sci. 7(11): 279-288. doi: https://doi.org/10.20546/ijcmas.2018.711.034 